GENETICS

\title{
In the world of Dolly, when does a human embryo acquire respect?
}

\author{
C Cameron, R Williamson
}

J Med Ethics 2005;31:215-220. doi: 10.1136/ime.2003.006395

For most of the 20th century, it was possible to regard fertilisation as the identifiable point when life begins, because this moment could be defined unequivocally and was thought to be the single most essential biological step in the establishment of a new human entity. Since the successful reproductive cloning of Dolly and other mammals, it is clear that any human cell has the potential to supply the full genome of an embryo, and hence a person, without going through fertilisation. At what point in time do such embryos acquire the respect accorded to human beings? The authors argue that the time of implantation is the most useful point at which the potential and the intention to create a new person are translated into reality, because from that point a new life develops. Implantation differentiates a somatic cell in culture (which is not due respect) from a human entity that has acquired its own identity and developmental potential. The authors examine the value of quickening or viability as alternative developmental stages in the process of acquiring respect for the Dolly embryo.

See end of article for authors' affiliations

\section{Correspondence to:} Correspondence to:
Professor R Williamson, The Dean's Ganglion, Faculty of Medicine, University of Melbourne, Melbourne 3070, Australia; r.williamson@ unimelb.edu.au

Received 4September 2003 In revised form 16 October 2003 Accepted for publication 2 November 2003
B efore 1827, when Von Baer discovered and described the female ovum and scientists began to understand fertilisation, ${ }^{1}$ little was known about the biological steps that occurred to create the human embryo. Aristotle, whose teachings formed much of our traditional philosophical understanding of the origin of the human individual, ${ }^{1}$ believed that a male's sperm reacted with the woman's blood in her womb causing it to develop into a living being. If the sperm (seed) remained in the womb for seven days from intercourse, conception would take place following the setting of the menstrual blood mixed with the semen, to form a single living being.

Aristotle pressed the comparison of the embryo to a seed sown in the ground whose parts are undifferentiated and in a state of potency until the first principle of growth becomes distinct when a shoot is put forward to provide nourishment. ${ }^{1}$ In the early embryo Aristotle found no evidence of any activity other than nourishment. He believed a nutritive or vegetative soul was acquired to enable nourishment and growth to take place. At around the 40th day, this nutritive soul was replaced by a "sensitive" soul when the organs required for sensation begin to develop, enabling the fetus to begin to enjoy animal life. Subsequently the "rational" soul appears, at a time not specified by Aristotle, from an undefined outside place, which completes the human form. Aristotle saw the "soul in man as the form of the body, the life-principle that enables matter to become a man in actuality."

Aristotle's view remained unchallenged for about two thousand years. ${ }^{1}$ Where there were differences, as with Thomas Aquinas, these were relatively minor. The fundamental theory was Aristotelian. The details of the theological debate on the timing of ensoulment are dealt with in Norman Ford's book When did I begin? Conception of the human individual in history, philosophy and science, ${ }^{1}$ and in the 2002 Annual Report of the President of the Royal Society, Lord May. ${ }^{2}$

After the discovery of the mechanism underlying embryogenesis in 1827, philosophers questioned Aristotle's theory of delayed rational animation. By the end of the 19th century, most Christian philosophers agreed that ensoulment (the religious counterpoint to the acquisition of respect as an individual) occurred at the time of fertilisation. Many contemporary philosophers still wish to uphold the tradition of immediate rational ensoulment from the time of conception. ${ }^{1}$ It has the great advantage of being simultaneously definitive and simple. Unfortunately, it no longer can be regarded as scientifically correct.

\section{RELIGION}

The Bible, the Koran, and the Talmud do not actually say when life begins, although each has been the subject of various interpretations. Within each religion, there is a wide range of views varying from radical to conservative. The advent of IVF posed a challenge to views that relied on definite intervals between fertilisation, implantation, quickening, and birth, as conception could occur outside the womb and implantation could be delayed for months or years. This uncertainty actually caused a firm reinforcement of the view among many religious philosophers that fertilisation is the critical step in creating a new human individual.

Let us begin by looking briefly at the views of a number of different religions, and a scientific (non-religious) and a modern philosophical view.

\section{Catholicism}

The traditional Catholic position is that life begins when the spiritual soul is infused into the human subject, which is at fertilisation. From that moment "every human life at every 
stage is equally worthy of protection"13 and its rights as a person should be recognised, including its right to life. In regard to embryos created by fertilisation in vitro, they are also "to be considered human creatures and subjects with rights: their dignity and right to life must be respected from the first moment of their existence" ${ }^{\prime 1}{ }^{4}$

Within the Catholic Church there are differing views on when life begins. "Many eminent Catholic moralists, both in previous centuries and today, particularly those relying on Aristotelian categories, have subscribed to theories of "delayed" or "mediate" animation-that is, that the soul is infused into the human subject at points later than fertilisation, with the corollary that individual human life and personhood do not begin until a later stage in the development of the human embryo." ${ }^{\prime 5}$ This less traditional view of delayed animation may enable recognition and respect for an embryo created other than by fertilisation. However it is difficult to envisage how traditional Catholics would view such an embryo/baby.

\section{Islamism}

Many Muslim scholars believe that ensoulment of the fetus does not occur until the fourth month of pregnancy (after 120 days), which is around the time quickening occurs. Such belief is based on passages from the Koran as well as narrations from the prophet Mohammed. The Prophet states "Each of you possesses his own formation within his mother's womb, first as a drop of matter for forty days, then as a blood clot for forty days, then as a blob for forty days, and then the angel is sent to breathe life into him."

However other Muslims interpret the Koran differently, and believe the "hanging embryo stage" starts about six days after fertilisation when the embryo attaches to the inner lining of the uterus. A human being is created from this tiny hanging embryo, and such individuals are entitled to protection. $^{7}$

\section{Buddhism}

Buddha provided that three conditions are required to be present for human life to begin: (1) intercourse must take place; (2) it must take place in "due season", that is, at the appropriate time in the menstrual cycle, and (3) the spirit of the being seeking rebirth must be at hand. If all three conditions are present the descent of the intermediate being may occur and a person will be created. Such events usually occur at the latest at the time of syngamy. ${ }^{8}$ Based on this traditional view, Buddhists do not "object to the technique of IVF in itself, since it merely assists nature in achieving its normal ends." ${ }^{\prime 8}$ After a minor detour nature is once again back on course, and the chain of normal development will resume. However they do not approve of the methods used in IVF. ${ }^{8}$ From these views, it is hard to speculate on what the attitude of Buddhists would be to an embryo created other than by fertilisation.

\section{Judaism}

"Jewish law does not regard a fertilised egg as a person before it is implanted in the womb" $b^{\prime \prime}$ and processes invisible to the human eye are not forbidden by Jewish law. Until the embryo is implanted the fertilised egg does not have the ethical status of a person. ' Many Jewish leaders make a fundamental distinction between the embryo in the earlier and later periods of pregnancy. Thus an embryo created other than by fertilisation would probably be recognised under Jewish law. As in Aristotelian philosophy, 40 days is postulated as a significant time in the development of the embryo. ${ }^{10}$ It is interesting to note that this is the time of closure of the neural tube, a time that has been interpreted as the beginning of a capacity for sentience in the embryo.

\section{Scientific view}

Most scientists do not believe that a new human life can be defined as beginning at any particular moment, but see it as evolving gradually during embryonic development. This is particularly true if the Darwinist view of evolution is taken into account, because human development in utero encapsulates the processes of development for many other species.

Many scientists see the appearance of the primitive streak in the embryo at 14 days as an important stage in development. "Before fourteen days the embryo, or preembryo as it was scientifically known, was a loose cluster of first two, then four, then sixteen cells, undifferentiated. An undifferentiated cell could develop into any of the types of cell that go to make up the human body, and some of them would not become part of the embryo at all, but would form the placenta." ${ }^{11}$ After 14 days, the primitive streak appears, twinning is no longer a possibility, and the cells develop into particular lineages.

From this stage it is no longer legally possible to carry out research on human embryos, either in the UK or Australia. ${ }^{12}$ Because the appearance of the primitive streak corresponds to the beginning of neural (brain) function, many scientists will not carry out experiments on embryos older than 14 days. Although scientists regard development as a continuum, many argue that there is an increment of respect due to a human embryo at 14 days, and progressively after that time.

\section{Philosophical view}

One school of modern philosophy does not give the embryo moral status or respect as a person until the embryo, fetus, or child reaches a stage in its development at which it attains some recognisable intellectual ability, capacity, or brain function. "The question must be, what should lead us to accept the embryo or the foetus or the neonate or the child or anything at all as having that range of qualities that makes them persons." ${ }^{13}$ The answer given by Harris is "... a person will be any being capable of valuing its own existence." ${ }^{\prime 13}$ Michael Tooley believes "An organism possesses a serious right to life only if it possesses the concept of a self as a continuing subject of experiences and other mental states, and believes that it is itself such a continuing entity."14 Savulescu does not think we begin to exist as people or "morally relevant entities" until our brain begins to function (consciousness begins) which is at least at 20 weeks of fetal gestation. ${ }^{15}$

\section{Commentary}

Since discovering the scientific beginnings of human life, that embryos are created by fertilisation of an egg by a sperm, the Catholic Church has had a great interest in and written extensively about when human life begins, or at least when it deserves respect, particularly in the context of IVF embryos. It is perhaps ironic that of all the Churches, only the Catholics attempted, towards the end of the 19th century, to accommodate the new science of embryology in its doctrine, and because of this they now find themselves expressing conservative views. Other religions that have not stated their religious views as dogma have left themselves more flexibility in dealing with mammalian cloning, and an embryo created other than by fertilisation will be more readily accepted by members of such religions.

Some of the more liberal Catholic theologians, such as Dr Norman Ford, have adopted a more contemporary view on when life begins based on science, philosophy, history, and theology. Dr Ford, focusing more on the scientific development of the embryo, believes a human individual is not formed until the appearance of the primitive streak, around 14 days; although he advocates that human life should be respected from conception due to its potential-regardless of whether a human individual or person has already been 
formed. ${ }^{16}$ However, it is difficult to place this in the context of a doctrine that equates the time of fertilisation with the time of acquisition of personhood.

The view outlined above from some philosophers also poses problems by disregarding the issue of potential. The problems that arise in overuse of potential are clear from study of the Catholic position. On the other hand, ignoring potential implies that only a fully sentient human being is deserving of rights and respect, and this does not accord with legal or ethical constructs in most societies, even from those without religious views.

\section{WHAT HAS DOLLY CHANGED?}

Dolly the cloned sheep was created by fusing the nucleus of a mammary gland cell from an adult sheep with another sheep's enucleated egg. Dolly was born on 5 July 1996. In theory, the same process can create a human embryo. As of 2003, there are no data that a human being has been successfully created by this method, but most scientists agree it is possible in principle.

Cloning a mammalian embryo from a somatic cell (any cell of the body, other than a reproductive cell) ("Dolly cloning") does not use the genomes (genetic material) of either a sperm or an egg. At present, an enucleated egg cell is often used as a nurturing environment for the somatic cell nucleus that provides the genetic material for the new embryo, but the egg cell is a facilitative incubator and does not provide meaningful genetic input to the new individual. It is already possible to use a frog egg to nurture and activate the nucleus from an adult human cell and switch on genes that are characteristic of human embryonic stem cells. ${ }^{17}$ It is likely that it will only be a few years, if that, before scientists create a human embryo from the nucleus of a somatic cell without any egg or sperm components at all. It has recently been shown that fusion of an adult cell with an embryonic stem cell also gives a potential embryo with a genome from the adult. This raises the question: for a "Dolly clone", because there is no fertilisation, when does "life begin"? When does the embryo/fetus/baby acquire respect?

\section{So what has changed?}

- Fertilisation is no longer required to create an embryo;

- A sperm is no longer required to create an embryo;

- An egg may not be required to create an embryo;

- One or more embryos may be created that have the same DNA as another living individual;

- As with IVF:

(1) it is possible to create an embryo in a petri dish; and

(2) the embryo in a petri dish may be:

(3) implanted in the womb;

(4) frozen;

(5) used for scientific experimentation;

(6) discarded; or

(7) used in any other manner, whether or not legally and/ or morally acceptable, such as for therapy, or for human cloning (which is illegal in the UK and Australia).

At present scientists are only able to allow an embryo to develop in a Petri dish for approximately 14 days. Unless successfully implanted in the womb, the embryo will not develop and will die. However, let us consider the implications if, in the future, an embryo created other than by fertilisation can be developed and grown outside the womb past this stage. It is even possible to consider an artificial uterine environment that can sustain an embryo until the stage of "viability" (until it can survive independently). For such a human life, many important ethical issues will arise, including the issue of respect. Although many of the issues we discuss will apply in this context, we do not specifically address the issue of respect for such a life. We are discussing the events that are with us at present or likely to arise in the near future.

Embryos can be used for purposes other than reproduction. Since the passing of Australian Commonwealth legislation in 2002, it is legally permissible to use embryos (created before 5 April 2002) which are surplus to needs for IVF, for approved research. ${ }^{18}$

Before addressing the question of when an embryo created other than by fertilisation acquires respect, we will look at whether or not such an embryo falls within the definition of "an embryo".

\section{What is an "embryo"?}

An embryo is traditionally thought of as an unborn animal or human in the early stages of development which was created by fertilisation. It is now possible to create an embryo other than by fertilisation. Does such an embryo still fall within the definition of "an embryo" because it has been created differently? Traditional Catholics have difficulty viewing such "embryos" as human embryos as they are not formed by fertilisation, which since 1870 has been the definition of the timing of ensoulment. Indeed, until Dolly-cloning, most people would have assumed that every human embryo (including IVF embryos) would be created by fertilisation, as until that time a human being could not be created in any other way.

An "embryo" is defined in the dictionary as "an animal in the early stages of growth before hatching; a developing unborn human during the first eight weeks after conception ... something as yet undeveloped". ${ }^{19}$ This definition implies that an embryo is created by fertilisation, by reference to "eight weeks after conception". The New Oxford Dictionary of English includes in its definition of an embryo "an unborn human offspring especially in the first eight weeks from conception, after implantation but before all the organs are developed." ${ }^{\prime 20}$ This definition also envisages the embryo as having been conceived and defines it as being "after implantation". If an embryo is defined as only being the product of fertilisation of an egg by a sperm, then the product of Dolly-cloning is not an embryo even though it might give rise to a fetus, a child, and an adult in time. This is clearly nonsense.

A more modern definition is provided by Norman Ford who defines a human embryo as "a totipotent single-cell, group of contiguous cells, or a multicellular organism which has the inherent actual potential to continue species specific ie typical, human development, given a suitable environment". ${ }^{16}$ An embryo created other than by fertilisation may develop into a human being given the right environment and would have all the characteristics of an embryo created by fertilisation. Such an embryo falls within Norman Ford's definition, which we adopt in this paper.

A European Committee looking into the legality of human cloning was of the view "if illicitly a human clone were fathered [sic], he or she would be fully human and none of the arguments ... presented could be used to challenge his or her human dignity". ${ }^{21}$ We suggest that should an embryo be created other than by fertilisation and be implanted in a womb with the potential to develop to a fetus and a child, it is an embryo, the only difference being the manner in which it was created.

\section{A. WHEN DOES AN EMBRYO CREATED OTHER THAN BY FERTILISATION BEGIN TO ACQUIRE RESPECT/ PERSONHOOD? \\ Respect}

"Respect" has both an objective and a subjective component, the relevance or importance of which may vary depending on 
how and in what context it is used. In medicine, living human beings are accorded a significant level of respect that is not accorded to dead human beings, but even this is tempered in terms of value judgments on quality of life. In biology, greater respect is accorded to individuals who reproduce at a higher rate and contribute disproportionately to the survival and fitness of the species. In law, respect is treated as if objective, depending upon the circumstances in each particular case and what is reasonable and acceptable; not as much importance is given to variation between individuals. Modern philosophers see people earning respect only when they matter morally. For a family member, respect may be subjective and accorded irrespective of personal values, on the basis of a relationship alone. While recognising these ambiguities, we are subsuming all of these views into a single word, "respect", in this analysis.

Respect may be accorded to embryos on each or all of a variety of criteria, depending on their philosophical or religious views and their relationship to the embryo, including:

1. the development status of the embryo;

2. the embryo's potential;

3. the value of the embryo to other people or to themselves.

\section{When does a Dolly embryo acquire respect?}

Over the centuries a number of different positions have emerged as to when an embryo deserves respect as a human being. Since 1870, traditional Catholics have held the view that it acquires full respect at fertilisation. However, for embryos created by nuclear transfer in a laboratory, fertilisation does not occur and is not relevant. The Dolly embryo is no different genetically when in the laboratory from the somatic cell from which it is derived. It only acquires ethical value when both the intention and the capability for development into a person are simultaneously realised.

The most important stage in the development of an embryo created outside the womb, such as a Dolly embryo, is implantation, as without successful implantation the embryo cannot develop into a human being. Its potential to develop is theoretical until it is implanted; on implantation, it becomes real. Upon the successful act of implantation the embryo will begin to acquire respect, because after implantation development takes place (at least in principle) which, if uninterrupted, leads to the birth of a human being. The embryo is also at the stage when the primitive streak appears, the cells begin to differentiate, there is no longer any chance of twinning, and the embryo thereafter develops into a recognisable fetus. As Ford says, this may be regarded as a biological correlate of the definitive stage of individuality. ${ }^{1}$

Until implantation with the Dolly embryo, there is no clarity as to what the future will be of the cells in culture that could become an embryo. After implantation, there are no reasons why any embryo, whatever its origin, should be treated any differently from an embryo at the same stage created by fertilisation. It may be that the Dolly embryo is at high risk of spontaneous abortion, or of birth handicap, but in principle any embryo faces these risks at some level or other.

\section{Does an embryo in culture deserve any respect if its future is unknown?}

This is a difficult question. On the one hand, embryos created by IVF of an egg by a sperm and allowed to develop to the eight cell stage before implantation, with the intention to create a pregnancy, have always been treated with respect by doctors and scientists. This respect extends to IVF embryos that are used for experimentation. This latter case is comparable to the respect accorded to human cadavers by medical students in anatomy lessons. ${ }^{22}$ Most people would not accord this respect to sperm or egg cells before fertilisation. Somatic cells in culture are now comparable to IVF embryos in that they can also give rise to embryos if treated in a particular way and then implanted in a womb. However, somatic cells are constantly dividing, generating new cells, and dying, and it would be both unscientific and counterintuitive to accord respect to such cells.

We conclude that IVF embryos are entitled to some respect, if only modest, "because they are alive and because they are regarded by others as morally valuable", ${ }^{22}$ for example, by gamete donors. However, cells in culture from an individual are not due this respect even if they are being prepared for use with the intention of implantation so as to create an individual (something that is illegal in Australia and in many other countries).

It is logical to regard implantation as marking the beginning of life for embryos created other than by fertilisation. Indeed, "some biologists suggest that we should regard implantation itself as conception."1 For embryos created other than by fertilisation, such a suggestion makes sense.

\section{B. ACQUISITION OF RESPECT AFTER IMPLANTATION}

As discussed above, after implantation there is little difference between the development in the womb of an embryo created by fertilisation and a Dolly embryo. The only difference may be the higher risk of abortion or birth handicap for the Dolly embryo. For embryos created by fertilisation, implantation is also a very important stage in their development as without successful implantation they will not develop further. Implantation is followed by numerous important stages, including development of the primitive streak (immediately after implantation at around 14 days), fetal movement in the womb (quickening, at approximately 15-20 weeks), brain life and the capacity for sentience, viability, birth, and self awareness (post birth). ${ }^{23}$

Different religious and professional groups each have views as to which is the most important stage. Viability is the criterion favoured by many neonatologists and gynaecologists, particularly as a criterion for the time when abortion is no longer acceptable, ${ }^{23}$ but even this view is not universal.

We believe that it is no longer possible to identify a single time (such as fertilisation) at which an embryo acquires respect as a future person. In view of the new technologies, the process of development of the individual can be regarded as beginning at implantation. This would clearly state that cells in culture that are not used for implantation and have not been manipulated to form an embryo, do not deserve respect. This is important as it is clear that every cell in any adult can (in principle) give rise to an embryo if treated in a particular way and implanted. It has the additional advantage of distinguishing clearly between cells in culture in laboratories (which have the theoretical potential to become people but no opportunity to do so), and cells implanted in a womb that have acquired the potential to develop into an infant without further intervention.

After implantation, when the process of acquiring respect begins, the embryo acquires more respect as the pregnancy progresses, with quickening being an important stage. Respect continues to increase until viability. From the time of viability (currently approximately 26 weeks in most first world countries) the embryo should be entitled to full respect as a human being.

\section{Quickening}

"Quickening" is the time when the pregnant woman can feel the fetus move inside her womb. This usually takes place 15-20 weeks in the first pregnancy and earlier in subsequent pregnancies. 
Not all pregnancies that follow implantation proceed to a successful outcome; as many as one in three abort spontaneously. Perhaps for this reason, it appears that the mother's respect for the embryo/fetus gradually increases over time, as she becomes more aware of the developing fetus and more confident that it will proceed to term and become a baby. Quickening occurs shortly after the end of the first trimester, at which time the risk of spontaneous abortion decreases significantly. The mother's increase in respect can be equated with the increase in value she gives to the life of the fetus. "For the question about moral significance, the question that is, when do embryos morally matter, is quite obviously one that must be answered by judgment and decision, according to a particular moral standpoint. It is not a question of fact but a question of value. How much should we value human life in its early stages?" ${ }^{24}$ The value a mother places on the growing fetus increases as the pregnancy proceeds and the fetus develops.

Modern ultrasound equipment and advances in modern science also enable doctors and thus parents to know a lot more about the developing fetus. "It is now possible to detect many lethal fetal abnormalities with certainty by about 16 weeks gestation". ${ }^{1}$ A woman's anxiety about the risk of having an abnormal fetus is reduced by prenatal screening. If the screening gives a normal result, this provides reassurance of a probable healthy outcome to the pregnancy.

The significance of quickening is implicit in the views of the Muslim and Jewish religions. Historically, in England, "before the introduction of Lord Ellenborough's Act (1803) it was not a crime under English common law to carry out an abortion before quickening, which was described as " $\ldots$ the time when 'the infant is able to stir in the mother's womb', and which was generally around the fourteenth week of pregnancy". ${ }^{25}$

Many doctors are reluctant to perform an abortion after first trimester, signalling an increase in respect for the developing fetus. In England, Scotland, and Wales abortion is permitted by law when two doctors decide "that the pregnancy has not exceeded its 24th week and that the continuance of the pregnancy would involve risk ..."26 Despite this freedom, almost $90 \%$ of abortions are performed before 13 weeks and fewer than $2 \%$ take place after 19 weeks. ${ }^{27}$ "A growing number of doctors who are comfortable with early abortion decline to provide, or even refer, for later procedures. Many NHS hospitals have established arbitrary time limits of 12 or 14 weeks ..."28 beyond which they are unable or unwilling to carry out terminations of pregnancy.

Although quickening is an important stage in the development of the fetus, with a significant increase in respect for the fetus both from the mother/parents and doctors, it is variable in timing between individuals. The fact that no easily defined scientific event takes place makes it difficult to give it a high degree of importance as a benchmark for the acquisition of respect.

\section{Viability}

Viability is "the stage of fetal development at which the fetus can survive independently of the pregnant woman, given suitable intensive care" ${ }^{\prime 23}$ It is currently as early as 22 weeks in well equipped centres, depending upon the birth weight and developmental stage of the fetus. It should be noted that although a fetus can survive after intensive care from this age, the outcomes are not always good, and many neonatal units are reluctant to embark on resuscitation until 26 or 27 weeks of pregnancy. Although the fetus can survive outside the uterus, no longer dependent on its mother, its survival is totally dependent on technology. This is also the time when consciousness (in terms of responsiveness to environmental stimuli) begins. ${ }^{15}$

"Viability is the criterion favoured by many who work in the field of neonatology, and also by some gynaecologists who accept abortion but who also believe that at some stage in their development fetuses acquire a right to life after which they should not be aborted."23 John Wyatt, a neonatologist, believes the UK law that allows late abortions, "is morally and practically unsustainable". ${ }^{29} \mathrm{He}$ also notes that some parents are horrified when the option of late term abortion is explored.

As gestation progresses past the earliest stage of viability, the unborn fetus is increasingly respected. As it moves from dependent to independent and acquires the ability to survive outside the uterus, it must be regarded, legally and ethically, as a legal person entitled to the full set of rights of any other individual. ${ }^{23}$ If it is viable, it is arguable that it should have the same respect as a neonate. Some newborn full term babies are fully dependent on technology, requiring high maintenance and special care to survive. We do not believe that a fetus generated by cloning technology should be regarded differently to a fetus conceived by the union of an egg and sperm.

In Australia, the law only recognises a baby having rights as a person at birth. A child in the womb is only recognised as a person when it is "completely delivered from the body of its mother and has a separate and independent existence ... and is living by virtue of the functioning of its own organs" ${ }^{\prime 30}$ This would include a baby dependent on technology. It is difficult for an embryo or fetus to have any rights while it is in the womb. If it is born with a disability or deformity that is caused by an accident while in the womb, it may have a cause of action in negligence against the wrongdoer once it is born. ${ }^{31}$ However it is debatable whether a child should have a claim for a prenatal injury against a parent. Otherwise the child may have a claim against its mother for indiscretions during pregnancy, such as heavy smoking, drinking, or taking drugs. Even worse would be claims for "wrongful life" against one's parents, or indeed against a doctor, or the manufacturer of a defective batch of contraceptives. ${ }^{32}$

In some Australian states the offence of child destruction prohibits the intentional destruction of the life of a child capable of being born alive. "Capable of being born alive" is not defined, although there is "a presumption that a child is capable of being born alive at 28 weeks gestation, or it could be earlier". ${ }^{33}$ To date very few, if any, prosecutions have been brought under this legislation. The burden of proving a child was capable of being born alive and the "intent" to "unlawfully" destroy the life of the child would be difficult.

Despite the law, from an ethical point of view, many doctors feel that they owe some form of "professional duty of care to the (unborn) fetus".$^{29}$ If the fetus is viable and capable of surviving outside of the womb and having a "separate and independent existence" from its mother, it deserves the same respect as a child who is born, regardless of how it was created.

\section{CONCLUSION}

In Australia and most other western countries it is illegal for an embryo to be created by manipulating a somatic cell ("Dolly-cloning"), by fusing an adult cell with an embryonic stem cell, or by any process other than fertilisation, and allowing that embryo to develop. ${ }^{34}$ However the successful cloning of Dolly and other mammals has shown that cloning of human beings is possible. Regardless of the law, it is only a matter of time before such human cloning occurs. Such a person, although cloned, has the same ethical status as any other person, and would be due all the rights and dignity of any person in our society-legally and ethically. 
Respect for a cloned embryo will only begin when the embryo is successfully implanted in the womb. Before then, somatic cells in culture would not be due respect (even though they have the theoretical potential to become a clone). It is the successful act of implantation that gives a group of cells the ability to progress to a living human without further scientific intervention. Respect will gradually increase throughout the pregnancy as the embryo grows and develops with nourishment and the right environment, and as its prospects of being born alive and healthy increase.

Although quickening is an important time for both parents and doctors, as both become more confident and reassured about the health of the child to be born, it is essentially subjective. Viability is the time at which the embryo acquires the same respect as a newborn, its legal rights being realised upon birth. Once the child is born any time after viability, it is capable of surviving on its own-separately and independently of its mother-and in law it is recognised as a person.

\section{Authors' affiliations}

C Cameron, R Williamson, Murdoch Children's Research Institute, University of Melbourne Department of Paediatrics, Royal Children's Hospital, Melbourne, Australia

\section{REFERENCES}

1 Ford NM. When did I begin? Conception of the human individual in history, philosophy and science. Cambridge: Cambridge University Press, 1988.

2 The Royal Society, Anniversary Address 2002 (issued December 2002).

3 Tonti-Filippini N. The Catholic Church and reproductive technology. In Kuhse H, Singer P, eds. Bioethics: an anthology. Blackwell Philosophy Anthologies, 1993.

4 Congregation for the Doctrine of the Faith. Instruction on respect for human life in its origin and on the dignity of procreation-replies to certain questions of the day. Vatican City: Vatican Polyglot Press, 1987:18.

5 Uren WJ. How is it right to treat the human embryo? The embryo and stem cell research. PACIFICA, 2003; 16: No 2:2.

6 Sahih al-Bukhari (d. 870), Sahih al-Muslim (875). The Book of Destiny [qadar]. In Testimony of Abdulaziz Sachedina, PhD on Islamic perspectives on research with human embryonic stem cells. Ethical issues in human stem cell research, religious perspectives. Rockville, MD: NBAC, 2000; III:G1-G6.

7 Khalifa AA, Strickland C. Islamic perspective on pro life issues. Available at http://abortionismurder.org/quoran.shtml (accessed 17 February 2005).

8 Keown D. Buddhism and bioethics. Hampshire, UK: Palgrave Macmillan, 2001.
9 Genetic engineering: genetic manipulation. http://www.bloc.co.uk/religion/ ethics/abortion/relig-judaism5.shtml.

10 Jakobovits I. Jewish medical ethics: a comparative and historical study of the Jewish religious attitude to medicine and its practice. New York: Bloch Publishing Company Inc, 274, 1962.

11 Warnock M. Making babies. Is there a right to have children? Oxford: Oxford University Press, 35, 2002.

12 The Human Fertilisation and Embryology Act 1990, UK and Research Involving Human Embryos Act 2002, Commonwealth of Australia.

13 Harris J. The value of life: an introduction to medical ethics. London: Routledge, 1985.

14 Tooley M. Abortion and infanticide. In Singer P, ed. Philosophy and Public Affairs 2. Reprinted in Applied ethics: Oxford readings in philosophy, 1972;1:82.

15 Savulescu J. Abortion, embryo destruction and the future of value argument. J Med Ethics 2002;28:133-5.

16 Ford N. The prenatal person: ethics from conception to birth. Oxford: Blackwell Publishing, 2002.

17 Byrne JA, Simonsson S, Western PS, et al. Nuclei of adult mammalian somatic cells are directly reprogrammed to oct- 4 stem cell gene expression by amphibian oocytes. Curr Biol 2003;13:1206-13.

18 Research Involving Human Embryos Act 2002, s21(3)(b).

19 The New Penguin English Dictionary.

20 The New Oxford Dictionary of English Oxford: Clarendon Press 1998.

21 Hansen B, Schotsmans P. Stem cell research: a moral theological and ethical interpretation. 8. In: Lectures in Medicine. Belgian Faculties of Medicine, Bruxelles, 2003

22 Meyer MJ, Nelson $\sqcup$. Respecting what we destroy: reflections on human embryo research. Hastings Cent Rep 2001;31:16-23.

23 Gillon R. Is there a 'new ethics of abortion'? J Med Ethics 2001 ;27(Suppl II):ii5-9.

24 Warnock M. Do human cells have rights? Bioethics 1987;1:1-14.

25 Parliament of Australia, Department of the Parliamentary Library, Abortion Law in Australia, Research Paper 1 1998-99:8. Available at http:// www.aph.gov.au/library/pubs/rp/1998-99/99rp01.htm.

26 Hewson B. Reproductive autonomy and the ethics of abortion. J Med Ethics 2001;27(Suppl II):ii10-14.

27 Greenwood J. The new ethics of abortion. J Med Ethics 2001;27(Suppl II):ii2-4.

28 Furedi A. Issues for service providers: a response to points raised. J Med Ethics 2001;27(Suppl II):ii28-32.

29 Wyatt J. Medical paternalism and the fetus. J Med Ethics, 27(Suppl II): ii5-20.

30 Hutty Rv. [1953] VLR 338; [1953] ALR 689, Barry J; statutory definitions to the same effect have been provided by the Criminal Codes of Queensland, Tasmania, and Western Australia, and also by s20 of the Crimes Act (NSW). 31 Watt $v$ Rama [1972] VR 353.

32 Savulescu J. Is there a "right not to be born"? Reproductive decision making, options and the right to information. J Med Ethics 2002;28:65-7.

33 Skene L. Law and medical practice: rights, duties, claims and defenses. Butterworths, 1998:269.

34 Prohibition of Human Cloning Act 2002 (Cth) s13. 